\title{
Assessment of some Hygienic Parameters of Grasscutter (Thryonomys Swinderianus) Feeds in Cote D'Ivoire
}

\author{
N'Dede Theodore DJENI ${ }^{1 *}$, Zranseu Ella Benedicte AKA ${ }^{1}$, Yahaya KARAMOKO ${ }^{2}$, Yao \\ Jean-Baptiste Eric KOUASSI ${ }^{1}$, Agathe FANTODJI ${ }^{2}$ \\ ${ }^{1}$ Laboratory of Biotechnology and Food Microbiology, UFR-STA, \\ Nangui Abrogoua University, 02 BP 801 Abidjan, Côte d'Ivoire \\ ${ }^{2}$ Laboratory of Biology and animal cytology, UFR SN, \\ Nangui Abrogoua University, 02 BP 801 Abidjan 02 Côte d'Ivoire \\ tdjeni@yahoo.fr
}

\begin{abstract}
Samples $(n=62)$ of two categories of animal feeds were collected from University Nangui Abrogoua experimental farms to determine some microbiological parameters by enumerating total bacteria, indicator bacteria, yeasts and moulds, and determining aflatoxins levels. Samples were constituted by granulate and concentrate feeds which contained soybean meal, cassava chip, maize, spent grains, cottonseed meal, dried plant materials, crushed snail shell and salt as main ingredients. Results showed that grasscutter feeds had high bacterial count $\left(9.7 \times 10^{6}-1.3 \times 10^{7} \mathrm{cfu} / \mathrm{g}\right)$. Identification of colonies from both types of feeds led to various species namely Enterobacter sp., Acinetobacter baumanii and Acinetobacter lwoffii for bacteria groups and Mucor sp., Aspergillus sp. and Penicillium sp. for the fungi. Mucor $s p$ was the predominant mould isolates, representing more than 50\% of isolates, followed by Aspergillus sp. (35\%). Aflatoxins B1, B2, G1 and G2 were detected in almost all feeds. Aflatoxin B1 was the mycotoxin found in higher frequency (100\%) and its level was highest in granulate feed samples. The information from the present study will contribute to set appropriate measures by Ivorian authorities and to develop traceability systems and establish a HACCP system as well as Good Agricultural Programme for Côte d'Ivoire.
\end{abstract}

Keywords: Aflatoxins, Feeds, Grasscutter, total bacteria, yeast and moulds

\section{INTRODUCTION}

The most commonly consumed species of game meat by people living in rural areas of West African countries is the grasscutter [1]. Grasscutter meat is also a delicacy in big towns and cities in these countries, particulary in Côte d'Ivoire. The popularity and delicacy of the grasscutter meat among other reasons led to several studies on the animal with the primary aim of domesticating the species for large-scale farming and production of the meat for human consumption [1,2].

Indeed, in two decades, research on the grasscutters have increased considerably, so that from the state of hunting game in 1983, grasscutter became since 1994, a breeding animal. Better still, its intensive farming in close captivity constitutes a source of additional income for breeders. The evolution of production parameters recorded at experimental farms and the variety of results obtained particulary for for grasscutter feeding by different farms from 1994 to 2000 suggest that there is great improvement in the growth performance of grasscutters [3]. However, grasscutter feeds are perishable and can be sensitive to changes in temperature, humidity, oxidation and subject to attack from mould, bacteria, fungi, insects, mites, rodents, birds, etc. The microbiology of feed impacts on the health of livestock and the dissemination of bacteria through animal populations. Livestock-harbouring zoonotic agents may enter the human food chain, and consequentially cause human illness [4]. Thus, as feed hygiene plays an important role in the safety of foods of animal origin, stringent controls on the microbiology of animal feeds are a necessary part of any hazard analysis of critical control pointsbased protection of the human food chain [5].

The present study constitutes a survey to obtain data for total bacteria counts, Enterobacteria, coliforms, yeast and mould counts, as well as aflatoxins of grasscutter feeds collected from the experimental farm of Nangui Abrogoua University. These data will serve as an essential source of information to the traceability concept, developing Good Agricultural Practice (GAP) programmes, 
and also as an important prerequisite to the establishment of Hazard Analysis and Critical Control Point (HACCP) systems for the non conventional animal production sector in Côte d'Ivoire.

\section{Materials ANd Methods}

\subsection{Sampling}

Sisty two samples of feeds were collected from the storage areas of the University Nangui Abrogoua experimental farms. These samples consisted of 24 samples of concentrate feeds and 38 samples of granulate feeds. All samples were analyzed for total bacterial count, Enterobacteria and coliforms count, yeast and mould counts and aflatoxins. Sampling took place from May to August 2014. Sampling of feeds was performed according to established Community methods [6].

\subsection{Enumeration, Isolation and Identification of Bacteria and Fungi}

Preparation of stock solutions, inoculation of agar plates, cultivation and quantification of microorganisms were carried out according to Djeni et al. [7]. For all determinations, $10 \mathrm{~g}$ of the samples was homogenized in a stomacher with $90 \mathrm{ml}$ of sterile buffered peptone water (AES Laboratoire, Combourg, France). Tenfold serial dilutions of stomacher fluid were prepared and spreadplated for determination of micro-organism counts. Enumeration of coliforms was carried out using plates of Violet Red Bile Lactose agar (VRBL, Merck 10660, Merck, Darmstadt, Germany). The cultures were incubated for $48 \mathrm{~h}$ at $30^{\circ} \mathrm{C}$ for total coliforms and $44^{\circ} \mathrm{C}$ for faecal coliforms. The eosin methylene blue agar (Becton Dickinson GmbH, Heidelberg, Germany) was used to particularly enumerate and isolate E. coli, which grows on the medium giving a distinctive metallic green sheen colony. Aerobic mesophiles were enumerated on plates of plate count agar (PCA Oxoid Ltd, Basingstoke, UK) and incubated at $30^{\circ} \mathrm{C}$ for 2 days. Identification of organisms isolated was based on cultural characteristics, morphology of cells and biochemical tests. The media and reagents were prepared as described by Harrigan and McCance [8] and Speck [9].

Yeasts and moulds were enumerated on plates of Sabouraud-chloramphenicol agar (Fluka, Biochemica 89579, Sigma-Aldrich Chemie $\mathrm{GmbH}$ ) incubated at $30^{\circ} \mathrm{C}$ for 2 days. The moulds were identified based on examination of the colonial heads, phialides, conidiophores and presence or absence of footcells or rhizoids [10].

\subsection{Aflatoxin Extraction from Feeds and HPLC Analysis}

Aflatoxins from feeds were extracted following the method of Ce'spedes and G. J. Diaz [11], with slight modifications. Twenty (20) $\mathrm{g}$ of feed samples were extracted with $100 \mathrm{ml}$ acetonitrile: potassium chloride $(90: 10, \mathrm{v} / \mathrm{v})$. The extract was then filtered and the resultant filtrate further purified with a Sepak cleanup column (Merck). Three aliquots $(200 \mu \mathrm{l})$ of the purified extract were transferred into vials. The solvent was evaporated under nitrogen gas and the samples were stored at $4^{\circ} \mathrm{C}$. The dried samples were dissolved in $1 \mathrm{ml}$ acetonitrile: potassium chloride $(1: 1, \mathrm{v} / \mathrm{v})$ and filtered. An aliquot of the filtrate $(300 \mu \mathrm{l})$ was injected into a Shimadzu HPLC system (Shimadzu, model CRBGA, Kyoto, Japan). Separation was carried out isocratically using $\mathrm{H}_{3} \mathrm{PO} 4(0.33 \mathrm{M})$ : acetonitrile: propanol-2 (650:400:50, v/v/v) as the mobile phase. The flow rate was maintained at $0.5 \mathrm{ml} / \mathrm{min})$ and the fluoro- metric was used. Identification of aflatoxins (B1, B2, G1, and G2) in each sample was achieved by comparison with retention times of standard peaks. A series of each aflatoxin standards were used to construct a calibration curve. The equation obtained from the calibration curve was used to calculate the concentration of aflatoxins in each sample.

\subsection{Statistical Analyses}

One-way analyses of variance based on DUNCAN multiple tests with significant level $\alpha=0.05$ were performed in order to compare microbial contents of both types of feed samples, using XLSTAT software (Addinosoft Inc.).

\section{RESUlTS}

\subsection{Prevalence and Level of Microbial Populations from Grasscutter Feeds}

Enumeration; isolation and identification of bacteria and moulds in grasscutter feeds revealed the presence of several microbial groups in varying amounts. Table 1 shows results of the prevalence and loads of microbial population in both granulate and concentrate feeds. All concentrate samples $(100 \%)$ were positive for total bacteria, enterobacteria, coliforms and moulds. Total bacteria load in 
this type of feed varied between $1.8 \times 10^{5}$ et $5.0 \times 10^{7} \mathrm{cfu} / \mathrm{g}$, with an average of $3.0 \times 10^{5} \mathrm{cfu} / \mathrm{g}$. Fecal coliforms load reached $3.0 \times 10^{5}$, while mould load ranged between $3.0 \times 10^{2}$ and $5.0 \times 10^{4} \mathrm{cfu} / \mathrm{g}$. However, no mould was detected in granulate feed samples and only $31 \%(6 / 19)$ were contamined by fecal coliforms with an mean load of $8.3 \times 10^{2} \mathrm{cfu} / \mathrm{g}$ (Table 1), while over half of samples contained enterobacteria and total coliforms.

Table1: Mean values and range of total bacteria, Enterobacteria, coliforms and moulds counts of two grasscutter feed types.

\begin{tabular}{|c|c|c|c|c|c|c|}
\hline \multirow{3}{*}{ Microorganisms } & \multicolumn{3}{|c|}{ Granulate feed } & \multicolumn{3}{|c|}{ Concentrate feed } \\
\hline & \multirow{2}{*}{$\begin{array}{l}\text { No. of positive } \\
\text { samples/total } \\
\text { samples }\end{array}$} & \multicolumn{2}{|c|}{ Load (CFU/g) } & \multirow{2}{*}{$\begin{array}{c}\text { No. of positive } \\
\text { samples/total } \\
\text { samples }\end{array}$} & \multicolumn{2}{|c|}{ Load (CFU/g) } \\
\hline & & Mean & Range & & Mean & Range \\
\hline Aerobic Mesophiles & $38 / 38$ & $1.3 \times 10^{7 \mathrm{a}}$ & $2.0 \times 10^{4}-5.0 \times 10^{7}$ & $24 / 24$ & $9.7 \times 10^{6 \mathrm{a}}$ & $\begin{array}{l}1.8 \times 10^{5} \\
5.0 \times 10^{7}\end{array}$ \\
\hline Enterobacteria & $20 / 38$ & $2.5 \times 10^{3 a}$ & $<100-8.8 \times 10^{3}$ & $24 / 24$ & $8.4 \times 10^{5 \mathrm{~b}}$ & $\begin{array}{l}3.8 \times 10^{3}- \\
2.5 \times 10^{6}\end{array}$ \\
\hline Total coliforms & $20 / 38$ & $2.4 \times 10^{3 \mathrm{a}}$ & $<100-7.0 \times 10^{3}$ & $24 / 24$ & $3.8 \times 10^{5 \mathrm{~b}}$ & $\begin{array}{l}3.1 \times 10^{3}- \\
2.1 \times 10^{6}\end{array}$ \\
\hline Fecal coliforms & $12 / 38$ & $8.3 \times 10^{2 \mathrm{a}}$ & $<100-3.0 \times 10^{3}$ & $20 / 24$ & $3.0 \times 10^{5 \mathrm{~b}}$ & $\begin{array}{l}8.1 \times 10^{3}- \\
1.7 \times 10^{6}\end{array}$ \\
\hline Moulds & $0 / 38$ & $<1^{\mathrm{a}}$ & $<1$ & $24 / 24$ & $1.3 \times 10^{4 \mathrm{~b}}$ & $\begin{array}{l}3.0 \times 10^{2}- \\
5.0 \times 10^{4}\end{array}$ \\
\hline
\end{tabular}

Mean values with the same superscript in a same line are not significantly different $(P>0.05)$.

Identification of colonies from both enterobacteria and coliforms groups led to a single species namely Enterobacter sp. But, on Plate Count Agar, several morphologic groups were obtained after Gram staining, with a dominance of Gram positif cocci shapes (Identification not yet achieved). Some Gram negative rod shapes on this medium were identified as Acinetobacter baumanii and Acinetobacter lwoffii, the others were not able to be identified with the biochemical tests applied in this study. According to the moulds, the were clustered into 3 main genus based on their macroscopic and microscopic characteristics. These are particularly Mucor sp., Aspergillus sp. and Penicillium sp. Mucor sp was the predominant mould isolates, representing more than $50 \%$ of isolates, followed by Aspergillus sp. (35\%) (Table 2).

Table2: Genus of Moulds isolated from grasscutter concentrate feed.

\begin{tabular}{|l|l|l|l|}
\hline \multicolumn{1}{|c|}{ Type of feed } & \multicolumn{1}{|c|}{ Genus } & \multicolumn{1}{c|}{ Mean load (CFU/g) } & \multicolumn{1}{c|}{ Rate of isolation } \\
\hline Concentrate & Mucor $\mathrm{sp}$ & $2.9 \times 10^{4}$ & 52.17 \\
\hline & Aspergillus $\mathrm{sp}$ & $2.1 \times 10^{3}$ & 34.78 \\
\hline & Penicillium $\mathrm{sp}$ & $9.5 \times 10^{2}$ & 13.04 \\
\hline
\end{tabular}

\subsection{Aflatoxins Levels in Grasscutter Feeds}

Four aflatoxins (B1, B2, G1 and G2) were detected (figure 1) in feed samples with mean total content of $0.134 \mu \mathrm{g} / \mathrm{kg}$ in granulate feed samples and $0.015 \mu \mathrm{g} / \mathrm{kg}$ in concentrate samples. These aflatoxins were more frequent in granulate samples than conentrate samples (Table 3). Indeed, aflatoxins G2 and B2 were not detected in any concentrate sample. But they were present in at least one granulate sample. Concerning aflatoxin B1, it was detected in all samples of both feed categories with content of de 0,086 et $0,013 \mu \mathrm{g} / \mathrm{kg}$ respectively in granulate and concentrate feeds (Table 3).

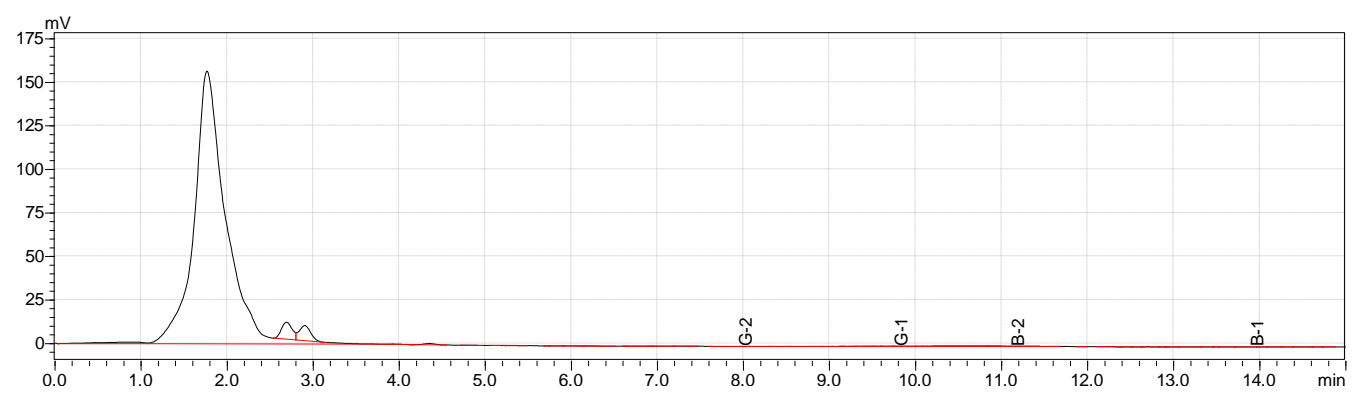

Figure1: Typical high-performance liquid chromatogram of extract of granulate feeds samples showing picks of aflatoxins B1, G1, G2 and their retention times. 
Table 3: Aflatoxins contents of two types of grasscutter feeds.

\begin{tabular}{|l|l|l|l|l|}
\hline \multirow{2}{*}{ Aflatoxins } & \multicolumn{2}{|c|}{ Granulate feed } & \multicolumn{2}{c|}{ Concentrate feed } \\
\cline { 2 - 5 } & $\begin{array}{c}\text { \%. of positive } \\
\text { samples }\end{array}$ & \multicolumn{1}{|c|}{$\begin{array}{c}\text { Highest Concentration } \\
(\boldsymbol{\mu g} / \mathbf{k g})\end{array}$} & $\begin{array}{c}\text { \% of positive } \\
\text { samples }\end{array}$ & $\begin{array}{c}\text { Highest concentration } \\
(\boldsymbol{\mu g} / \mathbf{k g})\end{array}$ \\
\hline Aflatoxine G-2 & 60 & 0.141 & 0 & nd \\
\hline Aflatoxine G-1 & 60 & 0.002 & 40 & 0.002 \\
\hline Aflatoxine B-2 & 40 & 0.006 & 0 & $\mathrm{nd}$ \\
\hline Aflatoxine B-1 & 100 & 0.086 & 100 & 0.013 \\
\hline
\end{tabular}

nd : not detected

\section{DisCuSSION}

Permissible levels of various microorganisms in animal feeds have not yet been recommended or stipulated by Côte d'Ivoire or other authorities as far it may concern grasscutter. This is due to lack of data on typical values in this animal feeding system. Our study provides the first data on the microbial composition of grasscutter feeds stored moist under farm conditions. We restricted our study to cultivable organisms, which might result in underestimation of the microbial diversity in the feeds. In several ecosystems, additional species have been found by using culture independent identification methods. However, usually results were in good agreement with those of culture dependent methods as reported by Masoud et al., [12] and van Beek and Priest [13].

Among feeds examined, granulate feed was microbiologically best, and concentrate one was worst. This may reflect the processing and storage methods of the feeds. Mould populations were highest in concentrate feed. In general, values for moulds tended to be high in low moisture content product. Although official National standards for microbial count do not exist, however, there are informal standards that are used as working guidelines for routine agricultural practice in some countries such as Greece [4]. According to these guidelines, bacterial populations of feeds should not exceed $10^{7}$, $8 \times 10^{6}$ or $4 \times 10^{6}$ for cereal grains other than maize, maize grain, and cottonseed meal, respectively. Following the same guidelines, yeast and fungi level should not exceed $2 \times 10^{5}, 10^{5}$, and $10^{5}$ for cereal grains other than maize, maize grain and cottonseed meal, respectively. Mean value of moulds counts of concentrate feeds in this study were below these values but the bacterial counts mainly Aerobic Mesophiles and Enterobacteria were in excess. The high number of Enterobacteriaceae in grasscutter feeds analyzed was unexpected, as it is assumed that these bacteria cannot grow at low moisture content [14]. This demonstrates a lake of Good Hygiene Practices and Good Agricultural Practice during farming. More over; the high proximity between feed storage place and farming site could have favour the contamination by effluent from animal framing to feed mainly by practicers.

Moulds cause deterioration of feeds, and produce off mycotoxins. Mycotoxins are of concern, as they can persist in the food chain. In our study, we isolated, among others, Aspegillus and Penicillum species, both genera that include potent producers of mycotoxins. Aflatoxins B1, B2, G1 and G2 were determined in feed samples by high performance liquid chromatography. Soybean meal, cassava chip, maize, spent grains, cottonseed meal, dried plant materials, crushed snail shell and salt were the main ingredients in samples. The presence of these aflatoxins were observed in most of the samples. Aflatoxin B1 was the mycotoxin found in higher frequency (100\%) and its level was highest in granulate feed samples. The current results are consistent with Siame et al. [15], who reported that aflatoxins were the most common toxins detected in foods and feeds samples containing sorghum and maize. Scudamore et al. [15, 16] have presented that aflatoxin B1 was the mycotoxin found most frequently in many sample of rice bran, maize products, palm kernels and cottonseeds. Aflatoxin B1 is a confirmed carcinogen [16], and its presence in plant materials was regulated in the EU at the time of this survey by Directive 99/29 [17]. According to Joint FAO/WHO Expert Commitee on Food Additives (JECFA), it was already concluded that a level of 0-20 ng/g of aflatoxin B1, a level of 0-50 $\mathrm{ng} / \mathrm{g}$ of total aflayoxins in food are within the tolerance limit [18]. In general, aflatoxin B1 does not seem to constitute a problem for feeds in Côte d'Ivoire as its content measured in this study $(0.086$ $\mu \mathrm{g} / \mathrm{kg}$ ) was below JECFA limits.

It appears that, regardless of the magnitude of infection, feeds of plant origin constitute potential sources of microbial infection, and this issue should be looked further. Animal feeding plays an essential role in microbial control, because it might be a potential carrier and infection source, and also because effective measures can be applied at this stage to control bacterial transmission. The microbiological hygiene of feeds is a requirement in any microbial control programme [19]. 
The information from the present study will contribute to set appropriate measures by Ivorian authorities and to develop traceability systems and establish a HACCP system as well as Good Agricultural Programme for Côte d'Ivoire.

\section{ACKNOWLEDGMENTS}

We acknowledge the financial support of the Wellcome Trust through Afrique One Consortium (One Health Initiative-African Research Consortium for Ecosystem and population Health). We also thank the staff of the Laboratoire National d'Appui au Développement Agricole (LANADA) for HPLC analyses of aflatoxins.

\section{REFERENCES}

[1] Asibey E. O. A., 1974. Wildlife as a source of protein in Africa South of the Sahara. Biological Conservation, 6 (1): 32-39

[2] Asibey E. O. A., 1978. Wildlife production as a means of protein supply in West Africa with particular reference to Ghana. Actes du $8^{\mathrm{e}}$ congrès forestier, Vol III: 869-881.

[3] Jori F. 2001. La cria de roedores tropicales (Thryonomys swinderianus y Atherurus africanus) como fuente de alimento en Gabon, Africa central. Thèse doctorale. Facultat de Veterinaria Universitat autonoma de Barcelona, $150 \mathrm{p}$.

[4] Vlachou S., Zoiopoulos P.E., Drosinos E.H. 2004. Assessment of some hygienic parameters of animal feeds in Greece. Animal Feed Science and Technology, 117: 331-337.

[5] den Hartog J. (2003) Feed for food: HACCP in the animal feed industry. Food Control 14, 9599.

[6] EEC 1976. First Commission Directive 76/371/EEC of 1 March 1976 establishing community methods of sampling for the official control of feedingstuffs. Official Journal of European Communities, L102: 1-7.

[7] Djeni N. T. N'guessan K. F., Toka D. M., Kouame K. A. and Dje K. M. 2011. Quality of attieke (a Fermented Cassava Product) from the Three Main Processing Zones in Côte d'Ivoire," Food Research International, 44 (1): 410-416.

[8] Harrigan W.F. and McCance M.E. 1976. Laboratory Methods in Food and Dairy Microbiology. London Academic Press, pp. 66-81.

[9] Speck L. 1976. Compendium of Methods for the Microbiological Analysis of Food. Washington, DC: American Public Health Association, pp. 417-483.

[10] Samson R.A. and Van Reenen-Hoekstra E.S. 1988. Introduction to Food Borne Fungi. 2nd edn. Baarn: Central bureau voor schimmel cultures, pp.239-249.

[11] Ce'spedes A. E. and Diaz G. J. 1997. Analysis of Aflatoxins in Poultry and Pig Feeds and Feedstuffs Used in Columbia. Journal AOAC International, 80 (6): 1215-1219.

[12] Van Beek S., Priest F.G. 2003. Bacterial diversity in scotch whisky fermentations as revealed by denaturing gradient gel electrophoresis. Journal of American Society of Brewing and Chemistry, 61. 10-14.

[13] Masoud W., Cesar L.B., Jespersen L., Jakobsen M., 2004. Yeast involved in fermentation of Coffea arabica in East Africa determined by genotyping and by direct denaturating gradient gel electrophoresis. Yeast, 21: 549-556.

[14] Adams M.R., Moss M.O., 2000. Food Microbiology. The Royal Society of Chemistry. Cambridge, England, pp. 37-45.

[15] Siame B.A., Mpuchane S.F., Gashe B.A., Allotey J., Teffera G. 1998. Occurence of aflatoxins, fumonisin B1 and zearalenone in foods and feeds in Bostwana. Journal of Food Protection, 61: 1670-1673.

[16] Scudamore K.A., Helmanski M.T., Chan H.K., Collins S. 1997a. Occurrence of mycotoxins in raw ingredients used for anima lfeeding stuffs in the United Kingdom in 1992. Food additives and Contaminants, 14: 157-173.

[17] Scudamore K.A., Helmanski M.T., Nawaz S., Naylor J., Rainbird S. 1997b. Determination of mycotoxins in per foods sold for domestic pets and wild bird using linked-column immunoassay clean-up and HPLC. Food additives and Contaminants, 14: 175-186. 
[18] Wogan G.N., Busby W.F., 1980. Naturally occurring carcinogens. In: Liener, I.E. (Ed.), Toxic Constituents of Plant Foodstuffs. Academic Press, New York, pp. 329-369.

[19] EU, 1999. Council Directive 1999/29/EC of 22 April 1999 on the undesirable substances and products in animal nutrition. Official Journal of European Communities, L115: 32-42.

[20] Bhat R. (1999). Mycotoxin contamination of foods and feeds. Working document FAO/WHO/UNEP Conference on Mycotoxins, Tunis, Tunisia.

[21] Coma J. 2003. Salmonella control in pork: effect of animal nutrition and feeding. Pig News Inform. $24,49 \mathrm{~N}-62 \mathrm{~N}$. 